\title{
A Structural Equation Model of CSR and Performance: Mediation by Innovation and Productivity
}

\author{
Khalid M. Al-Shuaibi ${ }^{1}$ \\ ${ }^{1}$ Business School - Rabigh, King Abdulaziz University, Jeddah, Saudi Arabia \\ Correspondence: Khalid M. Al-Shuaibi, Dean of Business School - Rabigh, King Abdulaziz University, Jeddah, \\ Saudi Arabia. E-mail: kshuaibi@hotmail.com
}

Received: May 2, 2016

Accepted: May 20, 2016 Online Published: May 23, 2016

doi:10.5539/jms.v6n2p139

URL: http://dx.doi.org/10.5539/jms.v6n2p139

\begin{abstract}
This study has explored the role of Innovation and productivity as mediating factors between Corporate Social Responsibility (CSR) and firm's Performance relationship. The objectives of this study are to build and test a theoretical model to identify the mediating factors in the linkage between CSR and performance.The theoretical model (CIPP Model) is deduced using strategic paradigm of literature. It consists of CSR, Innovation, Productivity, and Performance dimensions. Furthermore, several hypotheses were generated to examine the model. Structural Equation Modeling (SEM) is employed to test the model using data from CSR practicing firms 197 from Saudi Arabia. Confirmatory Factor Analysis (CFA) is performed followed by Structural Equation Modeling to examine the model. The results generally support the hypothesized model with research and managerial implications. The mediation of Innovation along with productivity in CSR linkage to performance isa major contribution to the literature, which may help to explore the black box in the relationship of CSR with performance. Besides proving the business case for the CSR in general, it also advocates the adoption of CSR practices by firms and MNEs operating in the developing countries, as it may enhance innovation and productivity leading to their increased financial performance. This model would be practical and useful for business managers that seek a competitive solution for succeeding in a business crisis and work in the settings of international business.
\end{abstract}

Keywords: Corporate Social Responsibility (CSR), innovation, productivity, financial performance, mediation, MNEs, developing country, Structural Equation Modeling (SEM)

\section{Introduction}

Corporate social responsibility (CSR) has grown to be an issue of much concern in the 21st Century for international business (Cegarra-Navarro et al., 2016; Kolk \& van Tulder, 2010). Hence, CSR has been increasingly getting more attention in international business studies (Park \& Ghauri, 2014). Multinational corporations (MNCs) and investors in international businesses are increasingly interested in the issue of socially responsible business around the globe (Besieux et al., 2015; Cruz \& Boehe, 2010).

The effect of CSR on the firm performance has attracted quite an interesting number of researchers recently. Although, most of the studies have found positive association between CSR and Financial performance (Cegarra-Navarro et al., 2016; Choi et al., 2010; Galbreath et al., 2014; Orlitzky et al., 2003; Surroca et al., 2010), yet few others hadfound a negative relationship (Marcus, 1989; Wright \& Ferris, 1997). While, some others still found no relation between the two (Aupperle et al., 1985; Teoh et al., 1999), therefore the question still remain unsettled (Aguinis \& Glavas, 2012). Such contradictory evidence has created ground to investigate this issue further and therefore, the requirement to model CSR effect on performance of firms and include factors that may mediate this path (Aguinis \& Glavas, 2012).

Furthermore, in literature, as proposed by Hart (1995), and empirically tested by Sharma \& Vredenburg(1998) that some firms while adopting CSR practices may develop few potential sources of competitive advantage; hence, emphasizing, the mediating role of few factors in the path from CSR to financial performance. McWilliams \& Siegel (2001) observed that this inconsistency in results of different studies might be the result of oversight of innovation or R\&D efforts of firm in the measurement models. Despite the fact that innovation is widely accepted as important construct in CSR literature, yet there have been very few studies to model and measure it as a mediatingfactor in CSR and firm's performance context. It was further observed in the study by 
Surroca et al. (2010) that certain intangible resources, might explain the missing link between CSR and financial performance of the firm. These intangible sources may include firm's efforts for increasing innovation and productivity.

Even though CSR and firms performance literature have ample of studies, yet, it has been still in the "continuing state of emergence" Lockett et al. (2006, p. 133), as far as the development of theory and methodology is concerned. Therefore, the objectives of this paper are to bridge the gap by building the theoretical model as well as testing it empirically. For the first time, this study has introduced the factors of innovation and productivity as mediators between CSR and financial Performance effect relationship.

Lately a number of CSR studies were premised on Porter hypothesis which states that well-built regulations may "trigger innovation" which may offset the cost implied with such regulations (Porter \& Vander Linde, 1998). CSR practices may steer the wheel of innovation (Cegarra-Navarro et al., 2016; McWilliams et al., 2006; McWilliams \& Siegel, 2001; Moon \& Choi, 2014; Spence, 2016). Different theoretical backgrounds can be applicable to relation of CSR with firm's innovation and productivity output.

Some studies have found positive relationship of CSR and productivity (Norris et al., 2012; Stuebs \& Sun, 2010; Tewari \& Nambudiri, 2012). But mostly their focus is on only one facet of productivity i.e., labor productivity, therefore, there is need to examine the effect of firms' level productivity as a factor in CSR implementation.

Despite all these partial theoretical contributions, there exists no theoretical model and empirical testing of mediating factors of innovation and productivity in CSR relationship with firm's performance. Consequently, there is a call to build a theoretical model premised on prevailing conceptual arguments, and employ a robust methodology to investigate it empirically. Hence, a theoretical model is developed to investigate this complex relationship of CSR with performance along with the mediating roles of innovation and productivity using Structural Equation Modeling (SEM) approach.

The significance of this study is multidimensional. Firstly, it is first endeavor of its kind to bridge the theoretical gap by focusing on the mediating process between CSR activities and performance of the firm. This study proposed Innovation and productivity as mediating variables for the path between CSR and firm performance. Very few studies have considered the relationship between CSR and innovation and even few discussed CSR and productivity association. Barely any study has modeled and analyzed the mediating roles of innovation and productivity.

Furthermore, this study attempts to fill the gap in literature regarding lack of research on CSR in Asian and developing countries (Egri \& Ralston, 2008). CSR is mostly reflected as a western phenomenon due to the presence of strongersystems as compared to developing countries (Chapple \& Moon, 2005; Tewari \& Pathak, 2015). This fact possibly will pose substantial challenge to the CSR practicing firms in these countries, like Saudi Arabia. Therefore, the objectives of this study are to build and test a theoretical model to identify the mediating factors in the linkage between CSR and performance in a developing country like Saudi Arabia.

The rest of the paper is organized as follows. In the next section, a theoretical framework is used to develop the model of CSR and performance of firms with prospective mediation of innovation and productivity to explain the missing link in the literature. The following section describes the methodology, sample and data of the study. It is followed by the summary of the data analysis. Then, concluded with findings together with theoretical contributions and implications for the managers. Finally, the limitations of the study with avenues for future research are listed.

\section{Literature Review}

In this section, a theoretical framework is built on the existing theoretical constructs. Then, a theoretical model is hypothesized using the existing paradigms of literature related to CSR, Innovation, Productivity and Performance of the firm.

\subsection{Corporate Social Responsibility (CSR)}

The concept of CSR elucidates the role of business in society (Vilanova et al., 2009), widely believed as one of the key issues for firms especially MNEs in twenty first century. In earlier studies, CSR concept has been advanced from diverse angles, such as business ethics (Solomon, 1992), social performance (Carroll, 1979; Swanson, 1995), corporate citizenship (Waddock, 2000; Zadek, 2001), stakeholder management (Donaldson \& Preston, 1995; Freeman, 1994; Lozano, 2005), and corporate governance (Freeman \& Evans, 1989). The concept of "doing well by doing well" articulates business case in favor of CSR in literature. That is, firms engaging in CSR earn certain number of rewards like increased financial performance (Orlitzky et al., 2003), reduced cost of doing business and financial risks (Godfrey, 2005), and enhanced corporate reputation (Turban \& Greening, 
1997), and better access to finance (Cheng et al., 2014). Despite the existence of many perspectives, Carroll's (1979) conceptualization of CSR continues a widely acknowledged approach, predominantly concerning empirical research. Based on Carroll (1979) framework, Maignan \& Ferrell $(1999,2000)$ revealed broad range of CSR activities and developed a framework comprising four dimensions to measure CSR practices:

- Economic Citizenship: Organizations must be profitable and productive, and must meet consumer needs.

- Legal Citizenship: Organizations must work within existing legal frameworks.

- Ethical Citizenship: they should follow socially established moral standards.

- Discretionary Citizenship: organizations must do corporate voluntary work to help other people and to contribute to the overall welfare of society.

\subsection{CSR and Financial Performance}

In literature, there are several models relating CSR and Profitability, mostly founded on the classical asset valuation theory that attributes rational behavior to the individuals (Fama \& French, 2004). In the field of Sustainable finance, the concept expands to the moral and social behavior of the agents, finding CSR as a tool for general welfare and societal benefits. Therefore, Zsolnai (2002) described economic agents as those whose moral psychology leads to their behavior. The literature has a lucid notion of firms' financial performance as the 'financial viability of an organization' (Price \& Mueller, 1986), Infact it is the degree to which a firm is able to achieve its financial and economic goals (Venkatraman \& Ramanujam, 1986). The sustainable competitive advantage for firms results from the intangible paybacks of CSR (Branco \& Rodrigues, 2006). Most of the studies found a positive relationship between CSR and Performance (Aupperle et al., 1985; Luo et al., 2014; Maignan et al., 1999; McGuire et al., 1988; McWilliams \& Siegel, 2000; Orlitzky, 2008; Orlitzky et al., 2003; Waddock \& Graves, 1997). CSR also reduces business risk (Moore, 2001; Orlitzky \& Benjamin, 2001). Certain event studiesalso prove that CSR increase the profitability (Frooman, 1997). Therefore, it can be conjectured from literature that CSR leads to better corporate financial performance of firms. Hence, the first hypothesis is:

$\boldsymbol{H}$ 1: There is a significant positive relationshipbetween CSR and financial performance.

\subsection{Mediating Factors}

Theoretically, there can be several internal and external paybacks, which can be outcome of CSR practices resulting in improved financial performances by CSR adopting firms (Aguinis \& Glavas, 2012).

In literature, focus has been on the performance outcome of CSR, yet there has been glossing over to the factors, which can be the contributor towards socially responsible performing firms. Therefore, a conceptual model is developed featuring innovation and productivity as potential missing link between CSR and firm performance.

\subsubsection{Innovation}

In literature, innovation is frequently operationa lised as the intensity of firm's investments in R\&D (Orlitzky \& Benjamin, 2001). CSR literature has distinguished the verity that the linkage between CSR and firms' financial performance cannot be well comprehended without taking the role of Innovation into consideration, (McWilliams et al., 2006; McWilliams \& Siegel, 2001). McWilliams \& Siegel (2000) pointed out that if the innovation in firms is statistically controlled, the positive relationship among CSR and firms' financial performance will disappear. There exists positive relationship between innovation and firm's financial performance (Geroski, 1994; Geroski et al., 1997). Certain studies have found the association between CSR and innovation (Waddock et al., 2002). Furthermore, from the methodology literature, it may be concluded that innovation has a tendency to heave the zero-order correlation between CSR and firms' financial performance proviso the relationship among innovation and CSR is positive instead of zero, or non-significant statistically (Schwab et al., 1999). Therefore, CSR acts as a means or vehicle for the innovation (Husted \& Allen, 2007, 2006), particularly in the cases where CSR is directed towards innovation (Maxfield, 2008). Indeed, innovation helps proving the business case for CSR (Maxfield, 2008). Therefore, this study postulates innovation as mediator between CSR and firm's financial performance as per following hypotheses:

H2: There is a significant positive relationship between CSR and innovation.

H3: There is a significant positive relationship between innovation and financial performance.

H4: Innovation mediates the relationship between CSR and Financial Performance.

\subsubsection{Productivity}

Schaltegger \& Figge (2000) linked CSR outcome with Efficiency gains. Heal (2005) in his theoretical research proved with giving case examples that CSR is positively associated with efficiency gains, improved employee 
productivity and reduced capital costs. Porter \& Vander Linde (1998) also found evidence in their research for association between CSR and increase efficient resource usage. Rondinelli \& London (2002) found the efficiency gains and cost reduction as outcome of CSR practices. Epstein \& Roy (2001) proved the efficiency gains \& cost reductions as business case for CSR with the help of both qualitative and quantitative analysis. Vilanova et al. (2009) argue that CSR leads to learning that generates innovative ideas and practices that lead to firm competitiveness. Vilanova et al. (2009) found productivity to be one fact of the firm competitiveness; which this study focuses on. This study anticipates a positive association between CSR and firm productivity, building on the premise of Porter \& Kramer (2011), and Vilanova et al. (2009), in similar vein as the earlier studies (Greening \& Turban, 2000; Porter \& Kramer, 2011; Stuebs \& Sun, 2010). CSR activities foster environment inside the firm, which may lead to higher productivity and in turn lead to the financial performance. Therefore, productivity can be postulated as mediator in CSR relationship with firm financial performance. Hence, the following hypotheses are formed:

\section{H5: There is a significant positive relationship between CSR and productivity.}

H6: There is a significant positive relationship between productivity and financial performance.

H7: Productivity mediates the relationship between CSR and Financial Performance.

\subsubsection{Innovation and Productivity Intermediation}

Crépon et al. $(2000,1998)$ showed empirically that innovation output drives firm productivity. Similarly, while using a sample of 735 service firms, Cainelli et al. (2006) found that innovation activities have positive impact on productivity. Moreover, productivity and innovation operate as a self-reinforcing mechanism, which further boosts performance. Norris et al. (2012) find that innovation has an effect on productivity. Therefore, following hypothesis is formed:

H8: There is intramediatory relationship of Innovation and Productivity in a relationship between CSR and financial performance.

\subsection{The Model and Hypotheses}

This study suggests a conceptual Model as deduced from the literature. The CIPP (CSR, Innovation, Productivity, Performance) Model consists of the following dimensions; CSR, Innovation, Productivity and Financial Performance (Figure 1). The hypotheses are shown in the figure below:

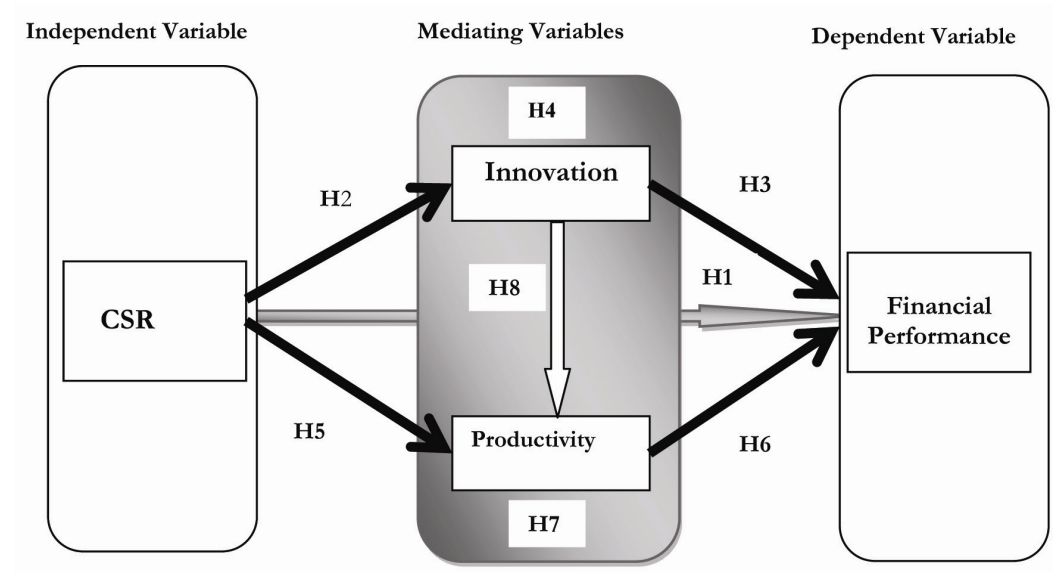

Figure 1. The CIPP model

\section{Research Design and Methodology}

In order to test the model hypothesis, this study administered survey using self-reported instruments. Confirmatory Factory Analysis was performed to test validity and reach a measurement model that was tested using Structural Equation Modeling (SEM) in AMOS.

\subsection{Questionnaire Design}

In order to conduct this empirical research, the variables in theoretical model were operated, using previously validated research instruments. The study adopts the instrument of Maignan \& Ferrell $(1999,2001)$ to measure CSR in hypothesized model. The respondents were asked to respond on1-5 Likert scale (Strongly Disagree to 
strongly agree) for activities of their corresponding firms. Innovation was measured usingthe instrument of Calantone et al. (2002). An indigenous set of questions were framed to measure the construct of productivity. These questions were set to measure total productivity, partial productivity, and growth in productivity in the firms of the respondents (Fried et al., 1993; Heizer \& Render, 2013). Financial performance of firms was measured using subjective measures (Venkatraman \& Ramanujam, 1986). We have used subjective measures of performance because of absence of public and objective performance data for all sample firms. Therefore, respondents were asked questions related to Return on Investment (ROI), Return on Assets (ROA), Return on Sales (ROS), and Profit Growth relative to their peers in industry similar to Maignan et al. $(1999,2001)$. The Likert scale of 1-3 was used where 1 stands for below Average, 2 for average and 3 for above average relative to their competitors.

\subsection{Sampling}

In order to test the hypotheses, the firms operating in Saudi Arabia were selected for this study. Saudi Arabia is ranked as one of highest in MENA region and 22nd (2013) in the world on the "Ease of Doing Business index" (ranking by World Bank group for being investment friendly) (World Bank, 2014). Hence, this study provides a platform to analyze the practices in a different business culture. Considering the environmental, business and cultural perspectives, it become paramount to study this theoretical model.

Saudi Arabia is an oil rich country with GDP of $\$ 1,681$ billion andranked 14th in the world (Purchasing Power Parity (PPP); 2015-World Bank data). The $60.4 \%$ of economy comprises of industrial sector, while $36.4 \%$ of services sector (World Bank, 2014). Over the past few years there has been growing awareness in Saudi Arabia about the environmental and social impacts of businesses on the society. Saudi Arabia being an emerging market with strong economy, yet growing industrial and services sector has made it an attractive source for an empirical study for CSR literature.

The companies were selected in a stepwise process. Tadawul All-Share Index (TASI) is the index of stock exchange in Saudi Arabia. In the first step, listed companies in TASI were selected. There are 165 listed companies in Saudi Arabia which were targeted for this study. Since, a reasonable number of large companies in Saudi Arabia are not listed, therefore, in the next step the 213 large and medium sized companies were selected from the directory of private companies published by the Ministry of Commerce and Industry of Saudi Arabia (Statistical Report, 2013). It makes the sample size of Saudi companies as 378.

\subsubsection{Survey and Response Rate}

The survey was sent to the person in-charge for the CSR in respective firmsusing both paper and web based platforms. Emails were sent as follow up to ensure better response rate. After receiving the responses, missing value analysis was performed and dropped the ones with high missing values. The remaining data includeda total of 197 responses, the response rate for combined sample is $52.12 \%$. It is anacceptable response rate as per the methodological studies (Anderson \& Gerbing, 1988; Hair \& Black, 2010).

\section{Data Analysis}

After data collection, data analysis is performed to examine the postulated model and its paths. The following section explains the steps taken.

\subsection{Analytical Strategy}

In order to do the analysis, a multipronged strategy was employed. Although, well-established instruments were used to measure the constructs, yet, second order Confirmatory factor analysis (CFA) is performed to investigate the validity and reliability of scales in Saudi Arabia using AMOS (Anderson \& Gerbing, 1988; Bentler, 1990). SPSS was used for reliability analysis. CFA was used to reach an adequate fit factor structure for the measurement model and to examine the convergent and discriminant validity (See Table 3 for details).

In the next step, Structural Equation Modeling (SEM) technique was used on the hypothesized structure. The target was to investigate the multimediation by Innovation and Productivity in CSR and Financial Performance relationship. In the following paragraphs, details of each step are narrated. Simultaneously, data is tested for common method variance using multiple methods to ensure the quality of the data (Podsakoff et al., 2003).

\subsection{Preliminary Analysis}

The hot deck method was used forreplacing missing value (Myers, 2011; Reilly, 1993). It was followed by the tests of normality, and exploratory factor analysis for preliminary results. The descriptive statistics of the sample are tabulated as below in Table 1. It is evident that the sample is well diversified. There have been responses from managers from different sectors, experience levels, and with various products. 
Table 1. Sample characteristics

\begin{tabular}{lcc}
\hline \multicolumn{2}{c}{ Frequency } & Percentage \\
\hline Type of operations & & \\
\hline Manufacturing & 95 & 48.22 \\
Services & 102 & 51.78 \\
Total & 197 & \\
\hline No of years & 49 & 24.87 \\
\hline 1- less than 5 years & 36 & 18.27 \\
5- less than 10 years & 40 & 20.3 \\
1o- less than 15 years & 72 & 36.55 \\
15 years or more & 197 & \\
Total & & \\
\hline No of products & 27 & 13.71 \\
\hline 1-3 & 32 & 16.24 \\
4-6 & 45 & 22.84 \\
7-12 & 93 & 47.21 \\
More than 12 & 197 & \\
Total & & \\
\hline
\end{tabular}

\subsection{Validity and Reliability Measurement}

A pilot study has checked the compatibility, and face and content validity of instruments used in the particular population and culture. The construct validity checks how well the results gained from the use of instrument do fit the theory (Cavana et al., 2001) and the content validity is checked by using the constructs that can be validated by peer experts. Both construct and content validity were examined in this study (Hair \& Black, 2010). The reliability of construct is deemed appropriate if value remains at least 0.7 for exploratory research and 0.8 for basic research (Nunnally, 1978). The Composite Reliability (CR), Cronbach alpha was calculated for measuring reliability while Average Variance Extracted (AVE), and Average Shared Variance (ASV) were measured to examine Discriminant Validity and Convergent Validity of factor structure (See Table 2). For convergent validity, the desirability range for AVE is to be higher than 0.5 and CR be greater than AVE and for discriminant validity, ASV should be less than AVE (Hair \& Black, 2010).

Table 2. Validity details

\begin{tabular}{lccc}
\hline & CR & AVE & ASV \\
\hline Innov & 0.86 & 0.55 & 0.32 \\
Prod & 0.76 & 0.52 & 0.11 \\
FP & 0.83 & 0.55 & 0.11 \\
CSR & 0.92 & 0.75 & 0.33 \\
\hline
\end{tabular}

Furthermore, the second order CFA was performed to measure construct validity and factor structure of the hypothesized model since CSR is second order construct in the study with four dimensions. Only items with higher loadings were retained to reach a factor structure to be further used. Table 3 shows the summary of CFA. It shows the corresponding factor structure and the loading items and their scores.

It is clear from results that the items on each factor met the requirements of reliability and validity (Nunnally, 1978). As the discriminant validity and convergent validity are not issue in the factor structure (See table 1), therefore next step is to measure the hypothesized paths using SEM. 
Table 3. Confirmatory factor analysis summary

\begin{tabular}{|c|c|c|c|}
\hline Variables & Code & Item Details & \\
\hline \multirow{4}{*}{$\begin{array}{c}\text { CSR } \\
\alpha=0.88, C R=0.92\end{array}$} & ECO & Economic citizenship & 0.92 \\
\hline & LEG & Legal citizenship & 0.77 \\
\hline & ETHIC & Ethical citizenship & 0.89 \\
\hline & ENV & Environmental/ discretionary Citizenship & 0.88 \\
\hline \multirow{5}{*}{$\begin{array}{l}\text { INNOVATION } \\
\alpha=0.857, C R=0.856\end{array}$} & INN1 & Our company frequently tries out new ideas & 0.81 \\
\hline & INN2 & Our company seeks out new ways to do things & 0.89 \\
\hline & INN3 & Our company is creative in its methods of operation & 0.82 \\
\hline & INN4 & Our company is often the first to market with new products and services & 0.67 \\
\hline & INN6 & Our new product introduction has increased over the last 5 years & 0.45 \\
\hline \multirow{3}{*}{$\begin{array}{l}\text { PRODUCTIVITY } \\
\alpha=0.75, C R=0.76\end{array}$} & PR1 & Always our company's output is greater than input & 0.81 \\
\hline & PR2 & In most cases, our company's output is greater than input & 0.82 \\
\hline & PR3 & In $50 \%$ of the cases, our company's output is greater than input & 0.5 \\
\hline \multirow{4}{*}{$\begin{array}{c}\text { Financial } \\
\text { Performance } \\
\alpha=0.86, C R=0.83,\end{array}$} & FP1 & Relative to our competitors, Our Return On Investment has been & 0.84 \\
\hline & FP2 & Relative to our competitors, Our Return On Assets has been & 0.67 \\
\hline & FP3 & Rela tive to our competitors, Our Sales Growth has been & 0.57 \\
\hline & FP4 & Relative to our competitors, Our Profit Growth has been & 0.86 \\
\hline \multirow{3}{*}{ ECO } & ECO1 & We closely monitor employees' productivity & 0.54 \\
\hline & $\mathrm{ECO} 3$ & We have been successful at maximizing our profits & 0.56 \\
\hline & $\mathrm{ECO} 4$ & Top management establishes long-term strategies for our business & 0.67 \\
\hline \multirow{3}{*}{ LEG } & LEG2 & All our products meet legal standards & 0.57 \\
\hline & LEG3 & The managers of this organization try to comply with the law & 0.78 \\
\hline & LEG4 & Our contractual obligations are always honored & 0.68 \\
\hline \multirow{7}{*}{ ETHIC } & ETH1 & Our business has a comprehensive code of conduct & 0.63 \\
\hline & ETH4 & We are recognized as a trustworthy company & 0.65 \\
\hline & ETH5 & $\begin{array}{l}\text { Fairness toward coworkers and business partners is an integral part of } \\
\text { our employee evaluation process }\end{array}$ & 0.78 \\
\hline & & A confidential procedure is in place for employees to report any & \\
\hline & ETH6 & misconduct at work (such as stealing or sexual harassment) & 0.7 \\
\hline & & Our salespersons and employees are required to provide full and accurate & \\
\hline & ETH7 & information to all customers & 0.6 \\
\hline \multirow{3}{*}{ ENV } & ENV3 & $\begin{array}{l}\text { Our business encourages employees to join civic organizations that } \\
\text { support our community }\end{array}$ & 0.61 \\
\hline & ENV5 & Our business gives adequate contributions to charities & 0.59 \\
\hline & ENV6 & $\begin{array}{l}\text { A program is in place to reduce the amount of energy and materials } \\
\text { wasted in our business }\end{array}$ & 0.71 \\
\hline
\end{tabular}

\subsection{Model Testing}

In this section, results of SEM for testing the direct path and hypothesized mediatory relationships are mentioned.

\subsubsection{Direct Path Testing}

In first step of testing the model by SEM, the first hypothesis direct path relationship between CSR and financial performance was tested. Figure 2 represents the model tested in AMOS.

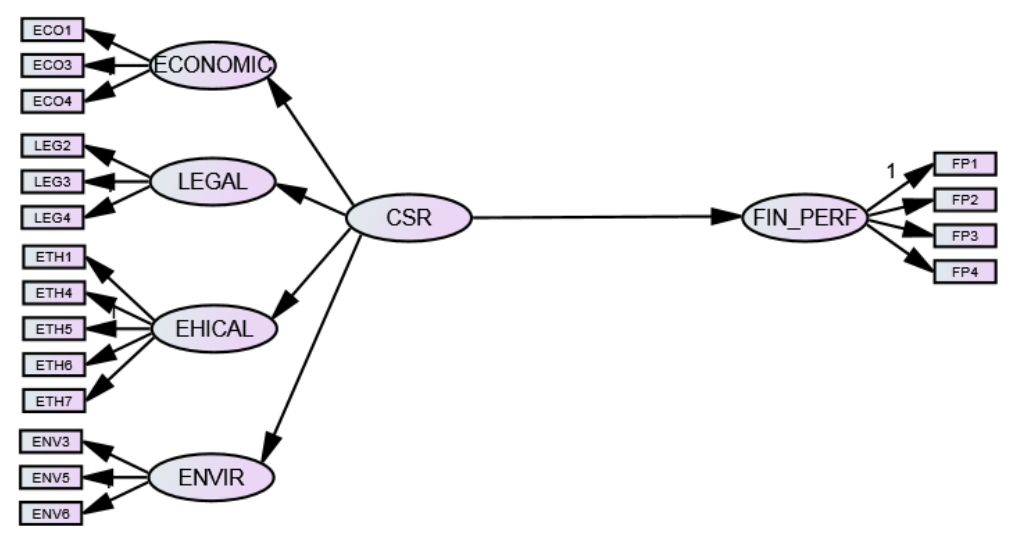

Figure 2. SEM direct path diagram 
The path between CSR and Financial Performance is significantly positive with $\beta=0.4 * *$. The Table 4 shows the details of path analysis with modification indices. It can be observed thatit shows adequate fit for the hypothesized path (Bentler, 1990; Hair \& Black, 2010). Therefore, H1 is accepted.

Table 4. SEM summary

\begin{tabular}{lcc}
\hline \multicolumn{1}{c}{ Hypothesized Relationships } & SA \\
\hline $\begin{array}{l}\text { Predictor } \\
\text { Variable }\end{array}$ & $\begin{array}{c}\text { Criterion } \\
\text { Variable }\end{array}$ & $\begin{array}{c}\text { Standardized } \\
\text { Regression } \\
\text { Weights }\end{array}$ \\
\hline CSR & FP & $0.4^{* *}$ \\
\hline \multicolumn{3}{c}{ Desirability } \\
Modification indices & Range & SA \\
\hline CMIN/DF & $<3$ good \\
RMR (Root Mean Squire & 1.82 \\
Residual) & $<0.09$ Good \\
IFI (Incremental Fit Index) & $>0.9$ Good & 0.05 \\
TLI (Tucker Lewis Index) & $>0.9$ Good & 0.93 \\
CFI (Comparative Fit Index) & $>0.9$ Good & 0.92 \\
RMSEA (Root Mean Squire & & \\
Error of Approximation) & $<0.08$ Good & 0.065 \\
\hline
\end{tabular}

\subsubsection{Hypothesized Model Testing}

In this step, the complete model was runto test the remaining hypotheses. A SEM path diagram was built in AMOS to run the tests. Figure 3 portrays the path diagram of the model structure.

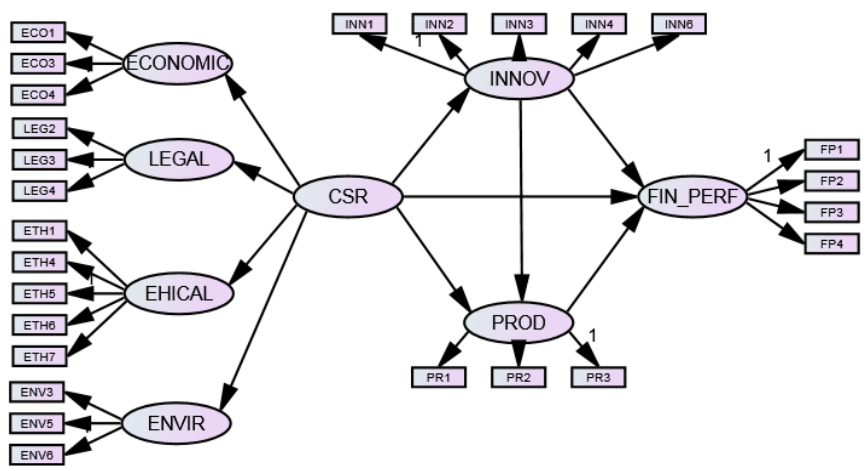

Figure 3. SEM path diagram of hypothesized model

Table 5. Initial model path analysis summary

\begin{tabular}{|c|c|c|}
\hline \multicolumn{2}{|c|}{ Hypothesized Relationships } & \multirow[b]{2}{*}{$\begin{array}{c}\text { Standardized } \\
\text { Regression } \\
\text { weights }\end{array}$} \\
\hline $\begin{array}{l}\text { Predictor } \\
\text { Variable }\end{array}$ & $\begin{array}{l}\text { Criterion } \\
\text { Variable }\end{array}$ & \\
\hline CSR & FP & 0.22 \\
\hline CSR & Innovation & $* * 0.81$ \\
\hline CSR & Productivity & 0.003 \\
\hline Innovation & Productivity & *0.39 \\
\hline Innovation & FP & 0.2 \\
\hline Productivity & $\mathrm{FP}$ & $* * 0.251$ \\
\hline Modification indices & $\begin{array}{l}\text { Desirability } \\
\text { Range }\end{array}$ & SA \\
\hline CMIN/DF & $<3$ good & 1.81 \\
\hline $\begin{array}{l}\text { RMR (Root Mean Squire } \\
\text { Residual) }\end{array}$ & $<0.09$ Good & 0.06 \\
\hline IFI (Incremental Fit Index) & $>0.9$ Good & 0.91 \\
\hline TLI (Tucker Lewis Index) & $>0.9$ Good & 0.9 \\
\hline CFI (Comparative Fit Index) & $>0.9$ Good & 0.9 \\
\hline $\begin{array}{l}\text { RMSEA (Root Mean Squire } \\
\text { Error of Approximation) }\end{array}$ & $<0.08$ Good & 0.06 \\
\hline PCLOSE & $>0.05$ Good & 0.01 \\
\hline
\end{tabular}


The SEM output for hypothesized relationships in the proposed model is given in Table 5. It can be seen that path for CSR to Financial Performance (FP) is not significant. Similarly, there is no significant relation between CSR and productivity as well as between Innovation and Financial performance. On the other hand, CSR and Innovation were found being strongly associated at $\beta=0.81$. Similarly, path from productivity to FP is significantly valued at $0.251^{* *}$ and $0.495^{* *}$. The modification indices are also under acceptable range as shown in the Table 5(Bentler, 1990). Hence, H2, H6 and H8 are accepted, whereas, H3 and H5 are rejected.

In light of this evidence, a new model was drawn by dropping the insignificant paths. In the following section, path analysis of the modified model will be discussed.

\subsubsection{Post-Analysis Model}

In light of the empirical evidence, the hypothesized model was modified as shown in Figure 5. It shows the path between CSR to Financial Performance (FP) completely mediated by Innovation and Productivity. The path shows relation from CSR to Innovation to Productivity to Financial Performance.

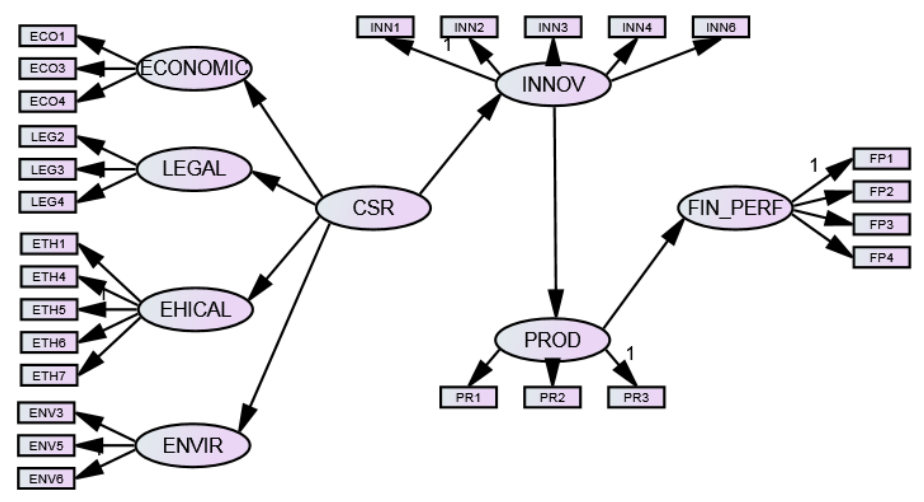

Figure 4. Post analysis SEM path diagram

In Table 6, co-efficient between CSR and Innovation, Innovation and productivity and between Productivity and Financial Performance (FP) shows the significant path. The proposition of innovation and productivity as mediators in path between CSR and FP is accepted. The co-efficient for CSR-innovation relationship is 0.803 in Saudi sample while Innovation-productivity is 0.425 . On the other hand, path coefficient from productivity to Financial Performance (FP) is 0.414 , being statistically significant at 0.05 .

It is evident from the results that modification indices are within acceptable range. These results show that innovation and productivity mediates the relationship between CSR and Financial Performance. There exists inter-mediatory relationship between innovation and productivity. Hence, the hypotheses regarding mediation (H4, H7 and H8) are accepted.

Table 6. Post analysis model path analysis summary

\begin{tabular}{lcc}
\hline \multicolumn{2}{c}{ Hypothesized Relationships } & SA \\
\hline \multicolumn{1}{c}{ Predictor Variable } & $\begin{array}{c}\text { Criterion } \\
\text { Variable }\end{array}$ & $\begin{array}{c}\text { Std. Regression } \\
\text { Weights }\end{array}$ \\
\hline \multicolumn{1}{c}{ Innovation } & Innovation & $0.803^{* *}$ \\
Productivity & Productivity & $0.425^{* *}$ \\
\multicolumn{1}{c}{ Modification indices } & Desirability & Range \\
\hline CMIN/DF & $<3$ good & 1.86 \\
RMR (Root Mean Squire & $<0.09$ Good & 0.07 \\
Residual) & SA \\
IFI (Incremental Fit Index) & $>0.9$ Good & 0.9 \\
TLI (Tucker Lewis Index) & $>0.9$ Good & 0.89 \\
CFI (Comparative Fit Index) & $>0.9$ Good & 0.9 \\
RMSEA (Root Mean Squire & $<0.08$ Good & 0.07 \\
Error of Approximation) & $<0.07$ \\
\hline
\end{tabular}




\section{Findings and Conclusion}

The objectives of this study were to build and test a theoretical model to identify the mediating factors in the linkage between CSR and performance in a developing country; Saudi Arabia. The results do indicate concisely that there is a mediation of Innovation and productivity in the CSR effect on the performance of firms in the study.

It is the first study of its kind, which couched on the premise that researchers have mainly glossed over the missing link between CSR and performance literature. The mediation by innovation and productivity explains this missing link. Consequently, a robust empirical enquiry was carried out to add, these mediating factors, to the theory. These findings offer several implications for theory and research on CSR, innovation, productivity and performance.

First of all, it is proved that there is a positive effect of CSR activities on the financial performance of the companies. It is lending credence to the business case of CSR in the firms especially Saudi companies (Aguinis \& Glavas, 2012; Besieux et al., 2015; He et al., 2012; Maignan \& Ferrell, 2000; Mefford \& Johnston, 2016; Orlitzky, 2008; Stuebs \& Sun, 2010; Udomkit, 2013; Waddock \& Graves, 1997).

Secondly, from the perspective of international business, an important finding is that that CSR is a vehicle for business performance not only in western and developed countries but also in developing countries as mentioned in earlier studies (Park \& Ghauri, 2014; Ritvala et al., 2014). Therefore, this research can be of interest to the Multinational Enterprises (MNEs) working or intend to work in these countries. It has attempted to fill the gap in literature regarding lack of research on CSR in Asian and developing countries (Egri \& Ralston, 2008).

Thirdly, it adds to the literature by solving the myths about the black box between CSR and financial performance. Therefore, this study advances and probes the factors that may mediate the CSR path to the firm's performance assuggested by McWilliams \& Siegel (2000). It also builds upon the research of Surroca et al. (2010) who suggested the mediation of certain factors between CSR and financial performance relationship. The mediating factors of innovation and productivity were proved as vehicle for financial paybacks after adopting CSR practices. In fact, it has been confirmed that CSR leads to innovation, which in turn enhances productivity leading to the firm's financial outcomes. The insignificance of direct path between CSR and productivity signified complete mediation through innovation. The findings of mediation by innovation in the path from CSR to productivity add another theoretical contribution toward CSR literature. The mediatory role of innovation is in line with the previous studies which distinguished the verity that the linkage between CSR and firms' financial performance cannot be well comprehended without taking the role of innovation into consideration (Burke \& Logsdon, 1996; McWilliams \& Siegel, 2001; Porter \& Kramer, 2011). Likewise, the path between innovation and financial performance is mediated by productivity. This study has suggested empirically by developing and testing a model that innovation and productivity are factors to be incorporated while practicing CSR in the firms. It advances the studies about CSR and innovation (Waddock et al., 2002), CSR and productivity (Paul \& Siegel, 2006; Shadbegian \& Gray, 2006; Stuebs \& Sun, 2010; Vitaliano \& Stella, 2006) and innovation and financial performance (Geroski, 1994; Geroski et al., 1997). Thus, this study has contributed to the literature of CSR and performance, by postulating the presence of mediatory roles of innovation and productivity.

Fourthly, it also endorses the OECD report (2009) about "new nature of innovation" which suggested that socially responsible acts in fact increasingly foster the innovation inside firms. In addition, the findings advocate that by CSR implementation at a strategic level leads to the creation of a competitive advantage by enhanced innovation and productivity which leads to improved firm's performance. This is in line with the Resource Based View (RBV) and strategic paradigms of literature (Asongu, 2007; Barney, 1991; Porter \& Kramer, 2011).

This study has attempted to fill the gap in literature about the mediating factors in the CSR and performance linkage. It is for the first time that the CSR - Performance model with multiple mediators was hypothesized and tested. Empirical evidence was found for these mediating relationships. It has added to the theory of strategic CSR that it provides an enabling environment for innovation which in turn enhances the productivity and performance of organization in line with the previous works (Asongu, 2007).

Moreover, it shows CSR awareness in Saudi Arabia where it is relatively a newer concept and certain previous studies already manifested the similar findings (Ali, 2009; Gravem, 2010; Naser \& Nuseibeh, 2003).

\section{Managerial Implications}

The findings have lucidly suggested that innovation and productivity are well enhanced under the CSR adapted firms. Innovation and productivity have both emerged as factors which are must to CSR adaptation in firms. Hence, there is implication for mangers that companies withCSR are higher in innovation output leads to 
improve in their productivity and performance.

On the practical managers' side, it has validated the concept of CSR implementation as a financially viable tool. It has added to the managers' tool to implement the CSR along with innovation and productivity as an intact approach with all leading to the objective of increased financial and economic value for the firms.

It has thus addressed the much concerned financial value issue for the local as well as foreign investors and multinationals working or intend to work in the MENA region especially Saudi Arabia. Thus, it provides the toolset of CSR implementation to the incumbent management and the investors of local as well as MNEs for the improved financial value of the firms. It has conjectured that CSR acts as a vehicle to enhanced innovation friendly environment with productivity improvement in the organization at same time all leading to better financial performance of the firms.

Consequently, it is ascertained in this study that this model of strategic CSR along with innovation and productivity may fetch both short and long term financial paybacks to a firm who is socially responsible. The management of MNEs with certain CSR programs must recognize that CSR as not being sheer charity or philanthropy rather it must be advanced from a strategic perspective as it helps improving innovation and productivity that brings financial benefits to the firm in total.

Ever since, private firms operating in Saudi Arabia were included the in the sample, the results proving the hypothesis of CSR leading to innovation, productivity and performance may also allure the private sector to invest in CSR activities as CSR is proved to enable environment fostering innovation and productivity and consequently improving financial performance of socially responsible firms.

\section{Limitations and Future Research Directions}

This study has shed the light on the mediating roles of innovation and productivity in the CSR and performance relationship. This study can be taken as point of departure for further enquiries into the black box between CSR and performance relationship. The study has been limited to use cross sectional data and single source of information, which can be checked and validated by using longitudinal and multisource data to avoid the common method variance associated with such type of studies. The financial performance was measured subjectively which can be validated by using objective measures to further validate the findings of this research.

Furthermore, the study has used Maignan \& Ferrell framework for measuring the CSR, but in future, other frameworks can be used to test these findings. The model is investigated in the perspective of only one country, yet the focus can be enlarged in future by inclusion of more countries on global level.

\section{References}

Aguinis, H., \& Glavas, A. (2012). What We Know and Don't Know About Corporate Social Responsibility A Review and Research Agenda. Journal of Management, 38, 932-968.

Ali, A. (2009). Business and management environment in Saudi Arabia: challenges and opportunities for multinational corporations. London: Routledge.

Anderson, J. C., \& Gerbing, D. W. (1988). Structural equation modeling in practice: A review and recommended two-step approach. Psychological Bulletin, 103, 411-423.

Asongu, J. J. (2007). Innovation as an argument for corporate social responsibility. Journal of Business and Public Policy, 1, 1-21.

Aupperle, K. E., Carroll, A. B., \& Hatfield, J. D. (1985). An Empirical Examination of the Relationship between Corporate Social Responsibility and Profitability. The Academy of Management Journal, 28, 446-463.

Barney, J. (1991). Firm resources and sustained competitive advantage. Journal of Management, 17, 99.

Bentler, P. M. (1990). Comparative fit indexes in structural models. Psychological Bbulletin, 107, 238.

Besieux, T., Baillien, E., Verbeke, A. L., \& Euwema, M. C. (2015). What goes around comes around: The mediation of corporate social responsibility in the relationship between transformational leadership and employee engagement. Economic and Industrial Democracy, 11.

Branco, M. C., \& Rodrigues, L. L. (2006). Corporate social responsibility and resource-based perspectives. Journal of Business Ethics, 69, 111-132.

Burke, L., \& Logsdon, J. M. (1996). How corporate social responsibility pays off. Long Range Planning, 29, 495-502. 
Cainelli, G., Evangelista, R., \& Savona, M. (2006). Innovation and economic performance in services: a firm-level analysis. Cambridge Journal of Economics, 30(3), 435-458.

Calantone, R. J., Cavusgil, S. T., \& Zhao, Y. (2002). Learning orientation, firm innovation capability, and firm performance. Industrial Marketing Management, 31, 515-524.

Carroll, A. B. (1979). A three-dimensional conceptual model of corporate performance. Academy of Management Review, 497-505.

Cavana, R. Y., Delahaye, B. L., \& Sekaran, U. (2001). Applied Business Research: Qualitative and Quantitative Methods. John Wiley \& Sons Australia, Limited.

Cegarra-Navarro, J. G., Reverte, C., Gómez-Melero, E., \& Wensley, A. K. (2016). Linking social and economic responsibilities with financial performance: The role of innovation. European Management Journal.

Chapple, W., \& Moon, J. (2005). Corporate Social Responsibility (CSR) in Asia A Seven-Country Study of CSR Web Site Reporting. Business and Society, 44, 415-441.

Cheng, B., Ioannou, I., \& Serafeim, G. (2014). Corporate social responsibility and access to finance. Strategic Management Journal, 35, 1-23.

Choi, J. S., Kwak, Y. M., \& Choe, C. (2010). Corporate social responsibility and corporate financial performance: Evidence from Korea. Australian Journal of Management, 35, 291-311.

Crépon, B., Duguet, E., \& Mairesse, J. (2000). Mesurer le rendement de l'innovation. Economie et statistique, 334, 65-78.

Crépon, B., Duguet, E., \& Mairessec, J. (1998). Research, Innovation and Productivity: An Econometric Analysis at the Firm Level. Economics of Innovation and new Technology, 7, 115-158.

Cruz, L. B., \& Boehe, D. M. (2010). How do Leading Retail MNCs Leverage CSR Globally? Insights from Brazil. Journal of Business Ethics, 91, 243-263.

Donaldson, T., \& Preston, L. E. (1995). The Stakeholder Theory of the Corporation: Concepts, Evidence, and Implications. The Academy of Management Review, 20, 65-91.

Egri, C. P., \& Ralston, D. A. (2008). Corporate responsibility: A review of international management research from 1998 to 2007. Journal of International Management, 14(4), 319-339.

Epstein, M. J., \& Roy, M. J. (2001). Sustainability in action: Identifying and measuring the key performance drivers. Long Range Planning, 34, 585-604.

Fama, E. F., \& French, K. R. (2004). The capital asset pricing model: theory and evidence. The Journal of Economic Perspectives, 18, 25-46.

Freeman, R. E. (1994). The politics of stakeholder theory: Some future directions. Business Ethics Quarterly, 4, 409-421.

Freeman, R. E., \& Evans, P. (1989). Stakeholder Management and the Modern Corporation: Kantian Capitalism. In T. L. Beauchamp \& N. Bowie (Eds.), Ethical Theory and Business. Englewood Cliffs, N.J.: Prentice Hall.

Fried, H. O., Schmidt, S. S., \& Lovell, C. A. K. (1993). The Measurement of Productive Efficiency. Techniques and Applications. Oxford: Oxford University Press, USA.

Frooman, J. (1997). Socially irresponsible and illegal behavior and shareholder wealth. Business \& Society, 36, 221.

Galbreath, J., Charles, D., \& Oczkowski, E. (2014). The Drivers of Climate Change Innovations: Evidence from the Australian Wine Industry. Journal of Business Ethics, 1-15.

Geroski, P. (1994). Market structure, corporate performance, and innovative activity. Oxford: Oxford University Press.

Geroski, P. A., Van Reenen, J., \& Walters, C. F. (1997). How persistently do firms innovate? Research Policy, $26,33-48$.

Godfrey, P. C. (2005). The relationship between corporate philanthropy and shareholder wealth: A risk management perspective. The Academy of Management Review, 777-798.

Gravem, O. M. B. (2010). Corporate Social Responsibility in Saudi Arabia. Middle East Policy, 19(4), 40-53. 
Greening, D. W., \& Turban, D. B. (2000). Corporate social performance as a competitive advantage in attracting a quality workforce. Business \& Society, 39, 254.

Hair, J. F., Black, W. C., Babin, B. J., \& Anderson, R. E. (2010). Multivariate Data Analysis. New Jersey: Pearson Prentice Hall.

Hart, S. L. (1995). A Natural-Resource-Based View of the Firm. The Academy of Management Review, 20, 986-1014.

He, H., Amezaga, T. R. W., \& Silva, B. O. (2012). Corporate Social Responsibility Perspectives and Practices in Chinese Companies: A Brief Overview on Environment, Consumers and External Communication. Journal of Management and Sustainability, 2, 57.

Heal, G. (2005). Corporate social responsibility: An economic and financial framework. The Geneva papers on risk and insurance-Issues and practice, 30, 387-409.

Heizer, J., \& Render, B. (2013). Operations Management. Pearson Education.

Husted, B. W., \& Allen, D. B. (2007). Corporate Social Strategy in Multinational Enterprises: Antecedents and Value Creation. Journal of Business Ethics, 74, 345-361.

Husted, B. W., \& Allen, D. B. (2006). Corporate social responsibility in the multinational enterprise: strategic and institutional approaches. Journal of International Business Studies, 37, 838-849.

Kolk, A., \& van Tulder, R. (2010). International business, corporate social responsibility and sustainable development. International Business Review, International Business, Corporate Social Responsibility and Sustainable Development, 19, 119-125.

Lockett, A., Moon, J., \& Visser, W. (2006). Corporate Social Responsibility in Management Research: Focus, Nature, Salience and Sources of Influence. Journal of Management Studies, 43, 115-136.

Lozano, J. M. (2005). Towards the relational corporation: from managing stakeholder relationships to building stakeholder relationships (waiting for Copernicus). Corporate Governance, 5, 60-77.

Luo, X., Wang, H., Raithel, S., \& Zheng, Q. (2014). Corporate social performance, analyst stock recommendations, and firm future returns. Strategic Management Journal in press, 36(1), 123-136.

Maignan, I., \& Ferrell, O. C. (2000). Measuring corporate citizenship in two countries: The case of the United States and France. Journal of Business Ethics, 23, 283-297.

Maignan, I., Ferrell, O. C., \& Hult, G. T. M. (1999). Corporate citizenship: cultural antecedents and business benefits. Journal of the Academy of Marketing Science, 27, 455-469.

Marcus, A. (1989). The deterrent to dubious corporate behavior: Profitability, probability and safety recalls. Strategic Management Journal, 10, 233-250.

Maxfield, S. (2008). Reconciling corporate citizenship and competitive strategy: Insights from economic theory. Journal of Business Ethics, 80, 367-377.

McGuire, J. B., Sundgren, A., \& Schneeweis, T. (1988). Corporate Social Responsibility and Firm Financial Performance. The Academy of Management Journal, 31, 854-872.

McWilliams, A., \& Siegel, D. (2000). Corporate social responsibility and financial performance: correlation or misspecification? Strategic Management Journal, 21, 603-609.

McWilliams, A., \& Siegel, D. (2001). Corporate social responsibility: A theory of the firm perspective. The Academy of Management Review, 26, 117-127.

McWilliams, A., Siegel, D. S., \& Wright, P. M. (2006). Corporate social responsibility: Strategic implications. Journal of Management Studies, 43, 1-18.

Mefford, R. N., \& Johnston, P. (2016). The Evolution of Sustainability in a Global Firm and Its Supply Chain. Journal of Management and Sustainability, 6, 77.

Moon, H. K., \& Choi, B. K. (2014). How an organization's ethical climate contributes to customer satisfaction and financial performance: Perceived organizational innovation perspective. European Journal of Innovation Management, 17, 85-106.

Moore, G. (2001). Corporate Social and Financial Performance: An Investigation in the U.K. Supermarket Industry. Journal of Business Ethics, 34, 299-315. 
Myers, T. A. (2011). Goodbye, listwise deletion: Presenting hot deck imputation as an easy and effective tool for handling missing data. Communication Methods and Measures, 5, 297-310.

Naser, K., \& Nuseibeh, R. (2003). Quality of financial reporting: evidence from the listed Saudi nonfinancial companies. The International Journal of Accounting, 38, 41-69.

Norris, E. D., Kersting, E. K., \& Verdier, G. (2012). Firm Productivity, Innovation, and Financial Development. Southern Economic Journal, 79, 422-449.

Nunnally, J. C. (1978). Psychometric theory. New Yock: McGraw-Hill.

Orlitzky, M. (2008). Corporate social performance and financial performance: A research synthesis. The Oxford handbook of corporate social responsibility, 113-134.

Orlitzky, M., \& Benjamin, J. D. (2001). Corporate social performance and firm risk: A meta-analytic review. Business \& Society, 40, 369.

Orlitzky, M., Schmidt, F. L., \& Rynes, S. L. (2003). Corporate social and financial performance: A meta-analysis. Organization studies, 24, 403.

Park, B. I., \& Ghauri, P. N. (2014). Determinants influencing CSR practices in small and medium sized MNE subsidiaries: A stakeholder perspective. Journal of World Business, 50(1), 192-204.

Paul, C. J. M., \& Siegel, D. S. (2006). Corporate social responsibility and economic performance. Journal of Productivity Analysis, 26, 207-211.

Podsakoff, P. M., MacKenzie, S. B., Lee, J. Y., \& Podsakoff, N. P. (2003). Common method biases in behavioral research: A critical review of the literature and recommended remedies. Journal of Applied Psychology, 88, 879-903.

Porter, M. E., \& Kramer, M. R. (2011). Creating shared value. Harvard business review, 89, 62-77.

Porter, M., \& Vander Linde, C. (1998). Green and Competitive, in: On Competition (pp. 351-375). Boston: Harvard Business School Publishing.

Price, J. L., \& Mueller, C. W. (1986). Absenteeism and turnover of hospital employees.

Reilly, M. (1993). Data analysis using hot deck multiple imputation. The Statistician, 307-313.

Ritvala, T., Salmi, A., \& Andersson, P. (2014). MNCs and local cross-sector partnerships: The case of a smarter Baltic Sea. International Business Review, 23(5), 942-951.

Rondinelli, D. A., \& London, T. (2002). Stakeholder and corporate responsibilities in crosssectoral environmental collaborations: Building value, legitimacy and trust. Unfolding stakeholder thinking: Theory, responsibility and engagement, 201-215. Sheffield: Greenleaf.

Schaltegger, S., \& Figge, F. (2000). Environmental shareholder value: economic success with corporate environmental management. Eco-Management and Auditing, 7, 29-42.

Schwab, K., Porter, M. E., \& Sachs, J. D. (1999). The global competitiveness report 1999. Oxford: Oxford University Press.

Shadbegian, R. J., \& Gray, W. B. (2006). Assessing multi-dimensional performance: environmental and economic outcomes. Journal of Productivity Analysis, 26(3), 213-234.

Sharma, S., \& Vredenburg, H. (1998). Proactive corporate environmental strategy and the development of competitively valuable organizational capabilities. Strategic Management Journal, 19, 729-753.

Solomon, R. C. (1992). Ethics and excellence: Cooperation and integrity in business. Oxford: Oxford University Press.

Spence, L. J. (2016). Small Business Social Responsibility Expanding Core CSR Theory. Business Society, 55, 23-55.

Statistical Report. (2013). Ministry of Commerce and Industry, Saudi Arabia.

Stuebs, M., \& Sun, L. (2010). Business Reputation and Labor Efficiency, Productivity, and Cost. Journal of Business Ethics, 96, 265-283.

Surroca, J., Tribó, J. A., \& Waddock, S. (2010). Corporate responsibility and financial performance: the role of intangible resources. Strategic Management Journal, 31, 463-490. 
Swanson, D. L. (1995). Addressing a theoretical problem by reorienting the corporate social performance model. Academy of Management Review, 43-64.

Teoh, S. H., Welch, I., \& Wazzan, C. P. (1999). The Effect of Socially Activist Investment Policies on the Financial Markets: Evidence from the South African Boycott. The Journal of Business, 72, 35-89.

Tewari, R., \& Nambudiri, R. (2012). Corporate Social Responsibility and Organizational Commitment: The Mediation of Job Satisfaction (SSRN Scholarly Paper No. ID 2034051). Social Science Research Network, Rochester, NY.

Tewari, R., \& Pathak, T. S. (2015). Sustainable CSR for Micro, Small and Medium Enterprises (SSRN Scholarly Paper No. ID 2600570). Social Science Research Network, Rochester, NY.

Turban, D. B., \& Greening, D. W. (1997). Corporate social performance and organizational attractiveness to prospective employees. Academy of Management Journal, 658-672.

Udomkit, N. (2013). CSR Analysis: A Reflection from Businesses and the Public in Thailand. Journal of Management and Sustainability, 3(2).

Venkatraman, N., \& Ramanujam, V. (1986). Measurement of business performance in strategy research: A comparison of approaches. Academy of Management Review, 801-814.

Vilanova, M., Lozano, J. M., \& Arenas, D. (2009). Exploring the nature of the relationship between CSR and competitiveness. Journal of Business Ethics, 87, 57-69.

Vitaliano, D. F., \& Stella, G. P. (2006). The cost of Corporate Social Responsibility: the case of the Community Reinvestment Act. Journal of Productivity Analysis, 26, 235-244.

Waddock, S. (2000). The multiple bottom lines of corporate citizenship: Social investing, reputation, and responsibility audits. Business and Society Review, 105, 323-345.

Waddock, S. A., \& Graves, S. B. (1997). The Corporate Social Performance-Financial Performance Link. Strategic Management Journal, 16(2), 61-78.

Waddock, S. A., Bodwell, C., \& Graves, S. B. (2002). Responsibility: The new business imperative. The Academy of Management Executive (1993-2005), 132-148.

World Bank. (2014). World bank GDP, PPP (current international \$) | Data | Table.

Wright, P., \& Ferris, S. P. (1997). Agency Conflict and Corporate Strategy: The Effect of Divestment on Corporate Value. Strategic Management Journal, 18, 77-83.

Zadek, S. (2001). The civil corporation: The new economy of corporate citizenship. Environmental Politics, $140(4), 475-478$.

Zsolnai, L. (2002). Ethics in the Economy, Handbook of Business Ethics (3rd ed.). Switzerland: Peter Lang-International Academic Publishers.

\section{Copyrights}

Copyright for this article is retained by the author(s), with first publication rights granted to the journal.

This is an open-access article distributed under the terms and conditions of the Creative Commons Attribution license (http://creativecommons.org/licenses/by/3.0/). 